\title{
Creation, humanity, science and sustainability for human survival
}

\author{
Dionysius S. K. Sharma ${ }^{1,2}$ \\ Published online: 13 November 2020 \\ (c) IUPESM and Springer-Verlag GmbH Germany, part of Springer Nature 2020
}

\section{Introduction}

John Anthony Burgess Wilson (1917-1993), the English writer and composer, wrote: "It's always good to remember where you come from and celebrate it. To remember where you come from is part of where you're going." Simply put, knowing your roots and your origins are vital for the journey forward in life. The profound words of Anthony Burgess (as he was known) apply so aptly to the history of life on Earth, from the beginning of time up to the present moment, and indeed well into the future. Whilst the past remains in a realm that cannot be undone-for science cannot turn back the clock - the future of all life on Earth; the vast possibilities of speciation and extinction, the continued evolution of species and indeed the continued survival of Homo sapiens (or its successor), by way of secularism lie in the hands of man.

Various religious beliefs and ideologies provide a narrative on the origins of the universe, the Earth and the origins of life forms, and the eschatology of several of these religions visualize the end of time (end of the world, Judgement Day), where humanity will face its ultimate destiny. Astrophysicists predict that the Sun will burn out in five billion years [1]. But well before that, in about a billion years, the Sun would be so hot that our oceans will boil and our planet will dry up. It is believed that this will spell the end of all life on Earth. If geological and evolutionary sciences inform us of our origins and predicts our end, and if that is inevitable, then we have what lies in between to be concerned about and to manage. Our ability to use science for the benefit of humanity and all life forms, our sustainable management of Earth's finite natural resources-but also our inevitable ecological footprint-may not change the predicted end, but

Dionysius S. K. Sharma

dionysiussharma@gmail.com

1 Malaysian Wildlife Conservation Foundation, Kuala Lumpur, Malaysia

2 Green Growth Asia Foundation, Melaka, Malaysia will surely determine the quality of our life on Earth and the survival of biological diversity in the remaining time we have left. As Anthony Burgess suggests, let us revisit our beginnings.

\section{The stories on creation and life on Earth}

In Chinese mythology, an enormous black egg contained the sleeping giant Pan $\mathrm{Gu}$, and when he died, his whole being started to form the world. Ancient Greeks believe that there was Chaos in the begining and out of the void emerged Gaia (the Earth). Iroquois Indians believe that the world was created on the back of a giant sea turtle while the Mayan Popol $V u h$ (The Book of the People) describes the creation of the earth by the wind of the sea and sky. In the Judeo-Christian creation narrative we learn from the Book of Genesis that it was God who created light, the Heavens and the Earth, water and land, plants and animals, and finally created man [2-5].

In science, the The Big Bang Theory is the widely accepted cosmological model for the universe as we know it, and it explains how the universe expanded some 13.8 billion years ago. Our own Solar System is calculated to have been formed some 4.6 billion years ago. Out of all the planets orbiting the Sun, and research results in the field of astronomy, Earth is the only astronomical object known to contain life forms that are familiar to us $[6,7]$. The earliest evidence of life on Earth comes from 4.28 billion year old fossilised microorganisms found in hydrothermal vents in Canada [8]. We have certainly come a long way since the earliest known life forms.

The biological diversity on Earth has varied throughout the history of the planet. Climatic changes and the shifting of landmasses over long timescales influenced the diversity and abundance of species. Species that could not adapt to the changes went extinct. As a result of natural selection, the DNA of a myriad of species continued to proliferate as new species were formed. The evolution of species is also affected by the mutation of genes. We know from geological and paleontological studies that the biodiversity on Earth 
has occasionally undergone mass extinctions, described as a period where the rate of species loss is much higher than usual. The first recorded mass extinction was the Great Oxygenation/Oxidation Event that occurred some 2.4 billion years ago. This resulted in the loss of most of the planet's obligate anaerobes. At the end of the Ordovician, 440 million years ago, $86 \%$ of all species went extinct and during the Late Devonian, 375 million years ago, $75 \%$ of species were gone forever. At the End of the Permian (also referred to as "The Great Dying") some 251 million years ago, 96\% of all species went extinct, including tabulate corals and most living trees at the time. At the End of the Triassic period (which spanned 50.6 million years ago and where the first true mammals appeared) some 200 million years ago, $80 \%$ of species were lost, including all of the conodonts, believed to be the first vertebrates.

And finally, we are more familiar with the End of the Cretaceous, some 66 million years ago, where $76 \%$ of species became extinct, including all of the ammonites, mosasaurs, ichthyosaurs, plesiosaurs, pterosaurs, and the land-dwelling dinosaurs [9-13].

\section{The advent of humans and their impact}

The available paleontological evidence of hominin evolution paints an interesting picture. Scientific evidence shows that the physical and behavioral traits shared by all people evolved over a period of approximately six million years. It is generally accepted that some 15 to 20 different species of early hominins are known to have walked the Earth. One of the earliest defining human traits, bipedalism-the ability to walk on two legs-evolved over 4 million years ago. We are all familiar with the discovery of "Lucy" (or Australopithecus afarensis) in 1974, a 3.2 million-year-old skeleton with both ape-like and human-like qualities discovered in Ethiopia [14, 15]. As recent as 2003, a hominin that stood only 3 feet and 7 inches, and nicknamed "The Hobbit", was discovered at Flores in Indonesia. Homo floresiensis went extinct 50,000 years ago [16]. Australopithecus sediba was discovered in 2008, and Homo naledi, yet another extinct species of hominin, was first discovered in 2015 at the Rising Star Cave System in South Africa [17]. This year, paleoanthropologists report of a new kind of hominid from the Philippines - Homo luzonensis [18]. Early humans first migrated out of Africa into Asia probably between 2 million and 1.8 million years ago. The beginnings of agriculture and the rise of the first civilizations occurred within the past 12,000 years.

As hominins spread across the globe, our abilities to make use of the available natural resources, make various tools, make fire to warm ourselves and cook, communicate and organise ourselves had a profound impact on terrestrial animals and the wider environment. On the one hand it was about hominins reaching places we never existed and on the other hand was our growth in numbers. We had an ability to wipe out a species, if it was of use to us, especially by overhunting.

A little over 6,000 years ago (ya)(c. 4000 BC) small populations of American mastodon begin to die off in places like Utah and Michigan; about 4,519 ya (c. 2500 BC) the last members of a dwarf race of woolly mammoths vanished from Wrangel Island near Alaska; approximately 619 ya (c. $1400)$ the moa and its predator, Haast's eagle, died out in New Zealand; 391 ya (1627) the last recorded wild aurochs died out; 331 ya (1688) the dodo became extinct; 251 ya (1768) Steller's sea cow became extinct; 136 ya (1883) the quagga, a subspecies of zebra, went extinct and about 105 ya (1914) Martha the last known passenger pigeon died.

Species extinctions have continued in the last hundred years. About 83 ya (1936) the last known thylacine (commonly known as the Tasmanian tiger) died in a Tasmanian zoo. About 67 ya (1952) the Caribbean monk seal became extinct and 11 ya (2008) the baiji, the Yangtze River dolphin, became functionally extinct, according to the IUCN (The International Union for the Conservation of Nature) Red List. As recent as 8 ya (2011) the western black rhinoceros was declared extinct [19-22].

In Peninsular Malaysia, the last two Javan rhinoceros were shot at Ujong Permatang, Selangor in 1928 and Telok Anson, Perak in 1932, respectively. Likewise, the Sumatran rhinoceros has been heavily poached for its horns and is now virtually extinct in Malaysia, where the last know if its kind died in captivity in Sabah on 23 November 2019. The nesting population of the Leatherback turtle along the Malaysian east coast state of Terengganu has declined to a point where there has been no nesting for the last seven years. This is attributed to harvesting of their eggs for human consumption and incidental capture and drowning in fishing gear. It has been estimated that 100,000 Bornean orang utans were lost between 1999 and 2015 [23], much of this loss correlated to loss of forested habitats. At the turn of twentieth century, $96 \%$ of Borneo was covered with rainforests. By 2005 , that was reduced to only $71 \%$ and by 2015 , down to only $55 \%$ (40 million hectares). The Malayan tiger, occurring only in Peninsular Malaysia is now possibly down to the last 200 animals, and on a continued declining population trend, and has been classified as Critically Endangered by IUCN. Rampant poaching, rather than habitat loss, is the primary driver of the declining Malayan tiger population. Without doubt, localised extinctions occur on just about every continent on the planet. In many instances it is not so much the loss of suitable habitat as it is rather rampant poaching and the illegal wildlife trade of wild animal parts and products.

Biological diversity (or simply biodiversity) refers to the variety and variability of life on Earth. Biodiversity is 
typically a measure of variation at the genetic, species, and ecosystem level. Our health (medical treatments), food production and security depends on biodiversity. Our economic activities depend on services provided by nature, globally estimated at US\$125 trillion a year [24]. Biodiversity is so important to us such that without healthy natural systems researchers are asking whether continuing human development is at all possible. Whilst we are able to assign a monetary value to the services of nature (e.g. climate regulation, pollination of crops, clean water), we are not too quick to set aside and retain enough nature for its value and ecosystem services.

Interestingly, whilst we record species extinctions, the field of scientific discovery continues. In 2015, the Royal Botanic Gardens at Kew reported that 2,034 new species of plants have been discovered-many have potential as food crops, medicines or sources of timber. Some 28,000 plants are now recorded as being of medicinal use. There are concerns among scientists that some of the newly-discovered plants are already at risk of extinction [25].

But scientific discoveries, scientific advancement and development, without sustainability and social responsibility in mind can have dire consequences. The manufacturing of plastics and its use may help illustrate the point. Since the 1950 s, the production and use of plastics has in many ways dominated other materials. The challenge is that numerous types of plastics are meant to be discarded after a single use. These move from domestic and industrial waste bins and into landfills. A lot of discarded plastics also end up in rivers and the open sea. It has been calculated that only nine per cent of the nine billion tons of plastic the world has ever produced has been recycled. The Asia Pacific Economic Cooperation (APEC) had estimated a staggering USD 13 billion impact of marine plastic pollution to the Asia Pacific region. Plastic wastes are now a major global environmental issue. Malaysia has been ranked 8th among the top ten countries with mismanaged plastic wastes in the world. The average Malaysian produced $800 \mathrm{gm}$ of solid waste a day in 2016 and the total waste generated per day in 2016 was 30,000 to 33,000 tons. Urban dwellers produced $1.25 \mathrm{~kg}$ of waste a day. Waste management authorities contend that an individual should not be producing more than $80 \mathrm{gm}$ of waste daily and what is happening in the urban areas is of concern.

The Malaysia government is committed to eliminate single-use plastic by 2030 and has identified lack of awareness, low recycling rate, biodegradability and cost of current alternatives to plastics, enforcement and integrated waste management as issues to be tackled [26].

Scientists now call the era we live in as the Anthropocene, a time where human impact on the planet is the primary driver of change, rather than any kinds of natural forces. The Living Planet Report 2018 reminds us that our species is producing and consuming unsustainably, and as a consequence, natural spaces, biological diversity and natural resources are being depleted rapidly. Species extinction rates are now 100 to 1,000 higher than rates of loss prior to the existence of humans [24].

Populations of mammals, birds, fish, reptiles, and amphibians have, on average, declined by $60 \%$ between 1970 and 2014. Earth is estimated to have lost approximately half of its shallow water corals in the past 30 years and one fifth of the Amazon has been lost in just 50 years. By 2050, it is projected that Africa may loose $50 \%$ of its birds and mammals, and by the same time, Asian fisheries are predicted to completely collapse. With a major reduction of plants, the absorbtion of carbon will be much reduced. Our changing climate will impact life-giving resources - clean water, food and clean air. Scientists estimate that between 2030 and 2050, the changes in Earth's climate is projected to result in some 25,000 additional deaths per year from lack of food, disease and heat stress. The costs to health, as a result, is estimated to be between USD2-4 billion per year by 2030 [24].

\section{Sustainable development as the way forward}

In 2015, the 193 countries of the United Nations General Assembly adopted the 2030 Development Agenda titled "Transforming our world: the 2030 Agenda for Sustainable Development". The 17 Sustainable Development Goals (SDGs) are broad and interdependent, and contain 169 targets. The SDGs cover social and economic development issues including poverty, hunger, health, education, global warming, gender equality, water, sanitation, energy, urbanization, environment (biodiversity on both land and sea) and social justice. Working hard to achieve these goals is without doubt timely and urgent. We are reminded of the words of Mr Ban Ki-moon, the United Nations Secretary-General from 2007 to 2016 where he said "We don't have Plan B because there is no Planet B" [27].

But even with these words of profound wisdom from $\mathrm{Mr}$ Ban Ki-moon, we know that space exploration continues to look towards the stars, in the hope of finding life, finding possible habitable planets for humanity and generally to understand the vast universe. TRAPPIST-1, a dwarf star in the Aquarius constellation, with 7 Earth-like planets orbiting it, was discovered in 2015. There is speculation that some planets here may support life as we know it. Given that it is 39 light-years away from Earth (369 trillion kilometers), NASA's Space Shuttle travelling at a maximum speed of about $28,000 \mathrm{~km} / \mathrm{h}$ would take around 1.5 million years to get there [28]. If at all possible, we will leave Earth as Homo sapiens and arrive there quite possibly something else. NASA's Budget for 2020 stands at USD 22.75 Billion, 
The European Space Agency budget stands at USD 15.5 Billion, and combined with that of China and Russia (albeit decreasing) surely adds up to a sizeable amount of money $[29,30]$. If there is no "Planet B" on the horizon, or to be discovered and reached in the foreseeable future, are we not better off using a portion of that valuable resource to help save our one and only home, planet Earth? Surely a major and concerted global momentum to reforest Earth will go a long way in capturing atmospheric carbon and minimize the looming danger and impacts of climate change.

So how has it come to be that after millions of years of evolution and the rise of Home sapiens some 200,000 years ago that we have ended up as a species that is highly capable of destroying the very environment that supports our existence? We continue to use science to invent and create machines, computers, systems, medicines to cure our diseases and ills, and our goal appears to be our desire to grow our national economies and improve our quality of life. Unfortunately, it can be argued that that is not necessarily homogenous across that planet, and, in many cases our increased standards of living and higher quality of life has been at the expense of biological diversity and the finite natural resources of Earth.

How has it come to be that as a species, we have now to be taught to understand that we simply cannot continue on this unsustainable development trajectory? The developments in the fields of medicine and healthcare, as agreed by the signatories of the United Nations Sustainable Development Goals (SDGs), are noble and necessary, as health is a fundamental human right. Poverty and poor health are strongly linked and the apex of our continued evolution surely will include doing away with investments that destructs humanity towards ones that builds and sustains humanity, and ensures quality health services for all. But well beyond merely keeping more of us alive for longer, we need to programme more of us to live sustainably, well into our extended years.

Laudato Si' (Praise be to You), released in 2015, is Pope Francis' historic encyclical on care for creation and our common home. It challenges us to "hear the cry of the earth and the cry of the poor" through ecological conversion, changes in lifestyle and society, and strong political action. The Pope writes that our "throw away culture" and pollution hurts the poor and we are reminded that care for the environment is a matter of intergenerational justice. In this day and age, it is really our indifference and attitude that separates us from the knowledge we have and the actions we ought to take to reduce our footprint on the planet and to live sustainable lives.

We are well informed by scientists as to where the biodiversity of Planet Earth is heading towards, as a result of the unsustainable living of our species. We know where we have come from and we now need to better define where we would like to head towards, and work at rectifying our past mistakes. And if we do, there may be a chance for this 200,000 year old Homo sapiens to survive well beyond the Anthropocene.

Acknowledgements I would like to thank Professor Dr Kwan-Hoong $\mathrm{Ng}$ of the Department of Biomedical Imaging \& University of Malaya Research Imaging Centre, University of Malaya, Kuala Lumpur and Professor Magdalena Stoeva, Medical University—Plovdiv, Bulgaria for inviting and encouraging me to write up this paper.

\section{Compliance with ethical standards}

Conflict of interest The authors declare that they have no conflict of interest.

\section{References}

1. Scudder J. The sun won't die for 5 billion years, so why do humans have only 1 billion years left on Earth? In: Phys.org. 2015. https ://phys.org/news/2015-02-sun-wont-die-billion-years.html. Accessed 5 Dec 2019.

2. Gill NS. Summaries of Ancient Creation Myths - Stories of Coming Into Being. In: Learn religions. 2018. https://www.learnrelig ions.com/ancient-creation-myths-117871. Accessed 9 Dec 2019.

3. Long CH. Creation myth. In: Encyclopedia Britannica. 2016. https ://www.britannica.com/topic/creation-myth. Accessed 9 Dec 2019

4. Holloway A. Reconstructing the history of humanity's past. The Maya myth of creation. In: Ancient Origins. 2013. https://www. ancient-origins.net/human-origins-folklore/maya-myth-creation0063. Accessed 9 Dec 2019.

5. Duignan-Cabrera A, Chao TX. The Top 10 Intelligent Designs (or Creation Myths). In: Live Science. 2014. https://www.livescienc e.com/11316-top-10-intelligent-designs-creation-myths.html. Accessed 9 Dec 2019.

6. Wall M. The Big Bang: What Really Happened at Our Universe's Birth? In: Science \& Astronomy. Space.Com. 2011. https://www. space.com/13347-big-bang-origins-universe-birth.html. Accessed 9 Dec 2019.

7. Choi CQ. What Makes Earth So Perfect for Life? In: Planet Earth, Live Science. 2012. https://www.livescience.com/31788-whyearth-perfect-for-life.html. Accessed 9 Dec 2019.

8. Drake N. This May Be the Oldest Known Sign of Life on Earth - Found embedded in crystal, the structures seem to be fossils formed around hydrothermal vents as much as 4.28 billion years ago. In: National Geographic, National Geographic Society. 2017. https://www.nationalgeographic.com/news/2017/03/oldest-lifeearth-iron-fossils-canada-vents-science/. Accessed 9 Dec 2019.

9. Greshko M and National Geographic Staff. What are mass extinctions, and what causes them? In: Science Explainer. National Geographic. National Geographic Society. 2019. https://www.natio nalgeographic.com/science/prehistoric-world/mass-extinction/. Accessed 10 Dec 2019.

10. Pariona A. Timeline Of Mass Extinction Events On Earth. WorldAtlas. 2018. https://www.worldatlas.com/articles/the-timelineof-the-mass-extinction-events-on-earth.html. Accessed 10 Dec 2019.

11. Tarlach G. The Six Mass Extinctions That Have Swept Our Planet. In: The Sciences. Discover Magazine. Kalmbach Media Co. 2018. https://www.discovermagazine.com/the-sciences/mass-extinction s. Accessed 10 Dec 2019.

12. Dapcevich M. Mass Extinction Event 2 Billion Years Ago Killed 99\% of Life on Earth, Study Finds. In: Science. EcoWatch.2019. 
https://www.ecowatch.com/serve-plants-save-planet-2641555444 .html?rebelltitem=1. Accessed 10 Dec 2019.

13. Cassella C. New Evidence Points to a Catastrophic Die-Off of Life on Earth 2 Billion Years Ago. In: Nature. Science Alert. 2019. https://www.sciencealert.com/even-more-evidence-arises-for-adie-off-bigger-than-the-dinosaurs. Accessed 10 Dec 2019.

14. Roberts A. Evolution - The Human Story. New York: DK Publishing; 2011. p. 256.

15. Harari YN. Sapiens - A brief history of humankind. London: Vintage Books; 2011. p. 498.

16. Mayell H. Hobbit-Like Human Ancestor Found in Asia. Washington DC: National Geographic. National Geographic Society; 2004. https://www.nationalgeographic.com/news/2004/10/human -ancestor-skeletons-indonesia/. Accessed 10 Dec 2019.

17. Berger L, Hawks J. Almost human. National Geographic Partners, LLC; 2017. p. 239.

18. Détroit F, Mijares AS, Cornyl J, et al. A new species of Homo from the Late Pleistocene of the Philippines. Nature. 2019. https ://doi.org/10.1038/s41586-019-1067-9.

19. McCaffery J, Nargi L. 14 Facts About Animals That Have Gone Extinct in the Last 100 Years. Readers Digest. 2015. https://www. rd.com/culture/animals-extinct-last-100-years/. Accessed 10 Dec 2019.

20. National Museum of National History. Extinction over time. Smithsonian Institution. 2019. https://naturalhistory.si.edu/ education/teaching-resources/paleontology/extinction-over-time. Accessed 10 Dec 2019.

21. Hirst KK. Mammoths and Mastodons - Ancient Extinct Elephants. ThoughtCo. 2019. https://www.thoughtco.com/mammoths-andmastodons-171039. Accessed 10 Dec 2019.

22. National Research Council (US) Committee on Scientific Issues in the Endangered Species Act. Science and the Endangered Species Act. 2, Species Extinctions. National Academies Press (US) Washington (DC). 1995. https://www.ncbi.nlm.nih.gov/books/ NBK232371/. Accessed 10 Dec 2019.

23. Voigt $\mathrm{M}$ et al. Global demand for natural resources eliminated more than 100,000 Bornean orangutans. Current Biology. 2018.
28:761-769. Elsevier Ltd. https://reader.elsevier.com/reader/ $\mathrm{sd} / \mathrm{pii} / \mathrm{S} 0960982218300861$ ?token $=$ C333AE9162664BC72115 D104BF6C95755BD6B2EF1614C0D6E2EC25028D88154A7 701011F71FBDA24F300BFAB14908958. Accessed 10 Dec 2019.

24. Grooten M, Almond, REA (Eds). Living Planet Report - 2018: Aiming Higher. WWF, Gland, Switzerland.

25. Morelle R. Kew report makes new tally for number of world's plants. In: Science and Environment. BBC News. 2016. https:// www.bbc.com/news/science-environment-36230858. Accessed 10 Dec 2019.

26. Ministry of Energy, Science, Technology, Environment and Climate Change. Malaysia's roadmap towards zero single-use plastics 2018-2030 - towards a sustainable future. 2018. MESTECC, Government of Malaysia, Putrajaya.

27. United Nations. Secretary-General's remarks to the press at COP22. 2016. Sustainable Development Goals. United Nations. https://www.un.org/sustainabledevelopment/blog/2016/11/secre tary-generals-remarks-to-the-press-at-cop22/. Accessed 2019.

28. Weitering H. TRAPPIST-1: How Long Would It Take to Fly to 7-Planet System? 2017. Space.com. https://www.space .com/35796-trappist-1-alien-planets-travel-time.html. Accessed 10 Dec 2019.

29. Goebel N. European Space Agency approves record budget. DW Akademie. 2019. https://www.dw.com/en/european-space-agenc y-approves-record-budget/a-51457014. Accessed 11 Dec 2019.

30. Foust J. Senate bill offers $\$ 22.75$ billion for NASA in 2020. Spacenews. 2019. https://spacenews.com/senate-bill-offers-22-75-billi on-for-nasa-in-2020/. Accessed 11 Dec 2019.

Publisher's note Springer Nature remains neutral with regard to jurisdictional claims in published maps and institutional affiliations. 